\title{
Underwater television for fisheries-independent stock assessment of Nephrops norvegicus from the Aegean (eastern Mediterranean) Sea
}

\author{
Christopher J. Smith ${ }^{1, *}$, Susan J. Marrs ${ }^{2,3}$, R. James A. Atkinson ${ }^{2}$, \\ K. Nadia Papadopoulou ${ }^{1}$, Jeremy M. Hills ${ }^{4}$ \\ ${ }^{1}$ Institute of Marine Biology of Crete, PO Box 2214, 71003 Iraklion, Crete, Greece \\ ${ }^{2}$ University Marine Biological Station Millport, 53 Marine Parade, Isle of Cumbrae KA28 0EG, United Kingdom \\ ${ }^{3}$ North Atlantic Fisheries College, Port Arthur, Scalloway, Shetland ZE1 0UN, United Kingdom \\ ${ }^{4}$ Centre for Coastal Management, University of Newcastle, Newcastle upon Tyne NE1 7RU, United Kingdom
}

\begin{abstract}
The underwater television (UWTV) technique for Nephrops stock assessment was evaluated from 7 grounds in the Aegean. Expert analysts made all burrow identification and burrow size measurements. Burrow density was given by (1) real-time in situ counts; (2) post-sampling laboratory replicate counts; and (3) multiple laboratory counts in strips analyzed by DISTANCE sampling in order to account for partial burrows and edge effects leading to over- or underestimation of densities. Trawls were used to estimate densities, mean carapace length and weight per ground. The laboratory method was the most efficient approach. In situ counts resulted in underestimation at high densities and overestimation at low densities. Further work with DISTANCE should include simulations with hypothetical data to optimise band widths related to the expected burrow size. All burrow density estimates produced similar significant negative relationships with burrow size and positive relationships with trawl density. Based on the tow length effects analysis, the use of tow lengths of 500 and $1000 \mathrm{~m}$ per station for high and mid-/low-density sites, respectively, is recommended. With expert analysts, laboratory counts, trawl support data, accurate delimitation of the grounds and adequate sampling spread to allow for local stock variability differences, the UWTV technique can be used for fishery-independent stock assessments, and its precision refined by taking into account edge effects.
\end{abstract}

KEY WORDS: Nephrops $\cdot$ Underwater video $\cdot$ Stock assessment $\cdot$ Aegean

\section{INTRODUCTION}

Traditional analytical stock assessment methods rely on analysis of long-term trends in fishery data (landings, effort, catch per unit effort [CPUE]), length and age-based assessments. Both length cohort analysis (LCA) and virtual population analysis (VPA) assessments are reliant on assumptions such as homogeneity of the stock, equal capture availability and stock redistribution criteria following capture of part of the stock (Caddy 1975). In search of alternative Nephropsspecific assessment approaches, a number of methods (e.g. depletion and dynamic production models) were applied recently to Nephrops fishery data from the Farn Deeps (North Sea). However, while it seems possible to get away from some of the assumptions underlying existing assessments, for example on growth, this seems to be at the expense of increased dependence on other assumptions, such as catchability patterns (Anonymous 2000). Fishery-independent surveys, on the other hand, have become an increasingly useful tool in the assessment of Nephrops stocks (Anonymous 2001) and could be a source of independent data with which to compare and fine-tune analytical methods (Anonymous 1999). Most suitable methods for Nephrops stocks include the use of underwater video to estimate 
the density of Nephrops burrows (Bailey et al. 1993, Anonymous 1994, Tuck et al. 1997b, 1999, Marrs et al. 1998) and spawning stock estimation with the larval production technique (Nichols et al. 1987, Smith 1987, Tuck et al. 1997b, Briggs et al. 2002).

The underwater television (UWTV) technique exploits the fact that Nephrops live in burrows that can be identified and enumerated, thus resulting in quantified video estimates of burrow density. The technique depends on adequate sampling of the ground, accurate burrow recognition and a satisfactory strategy for counting burrows. In situ counts of burrows in real time would clearly be the fastest method, and with data analysis on board, immediate presentation after a sampling cruise would be possible. The accuracy of this method versus post sampling ('laboratory') analysis, however, has not been investigated so far. Another issue relevant to interpreting UWTV videotape records is that of the inclusion, or not, of parts of burrows that are observed at the edge of the field of view. If these burrows are included in the analysis, then the actual area sampled will be greater than that of the field of view of the camera resulting in an overestimation. If only intact burrows are observed, it is possible that the area observed will be less than the actual field of view of the camera, resulting in an underestimation of burrow density. In this paper, a preliminary investigation of the program DISTANCE (www.ruwpa.st-and.ac.uk/distance/) was undertaken in an attempt to overcome the problem of partial and missing observations. Distance sampling is a widely used group of closely related methods for estimating the density and/or abundance of biological populations, and is an extension of quadrat-based line and point sampling methods (Buckland et al. 2001). Distance sampling extends these methods by (1) relaxing the assumption that all objects within the circle or strip are detected and therefore counted; and (2) expecting fewer detections with increasing distance from the centre of a strip transect. By measuring distances to the objects that are observed, the probability of observing an object within the circle or strip can be estimated. The key to distance sampling analyses, however, is to fit a detection function to the observed distances, and use this fitted function to estimate the proportion of objects missed by the survey (Thomas et al. 2002).

The work reported here is part of a research project for the calibration of the technique for Nephrops stock assessment. Three main tasks were identified in the Aegean component of the research relevant to sampling and analysis and optimisation: (1) to investigate burrow counting approaches, such as real-time in situ determinations and laboratory counts using video players for detailed observations; (2) to address the problem of partial observations and edge effects by exploring the use of the DISTANCE software; and (3) to investigate the effect of tow length to optimise sampling efficiency for stock assessment.

Other parts of the study, i.e. burrow casts, diver mapping, burrow structure, burrow identification, burrow occupancy criteria and burrow longevity after experimental disturbance are reported in Marrs et al. (1996).

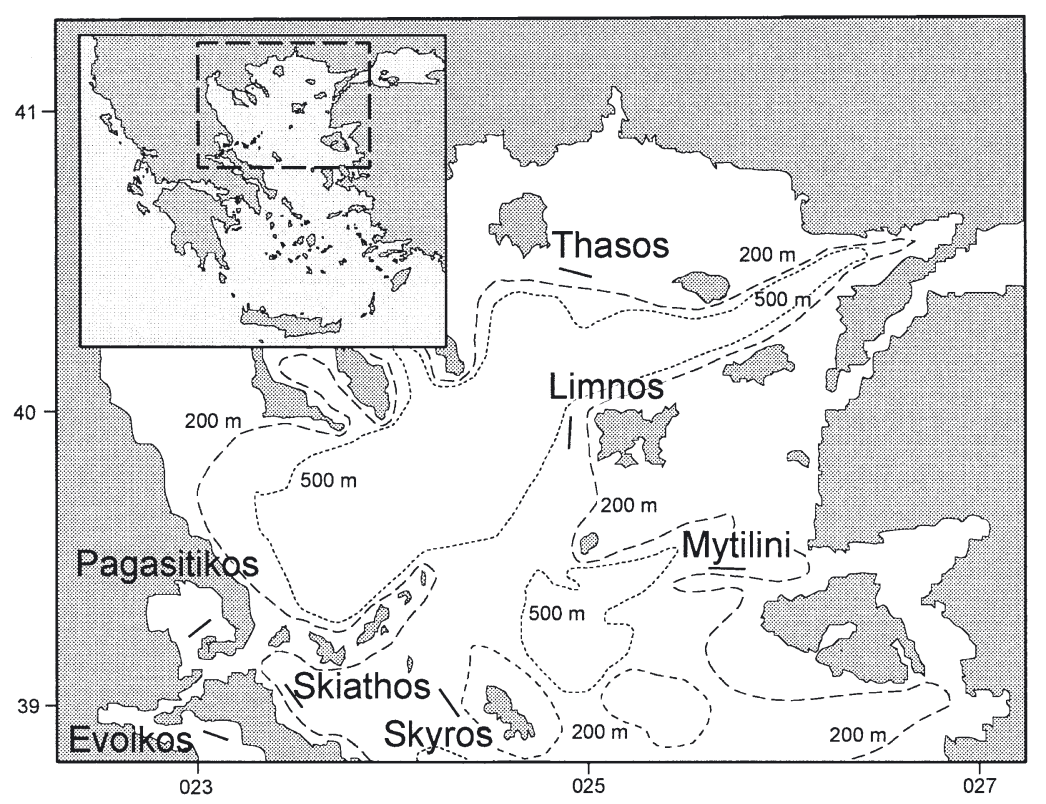

Fig. 1. The 7 Nephrops areas sampled in the northern Aegean (bar indicates approximate sledge tow and trawl areas)

\section{MATERIALS AND METHODS}

Sampling cruise. A total of 7 video sledge tows and 7 trawls were made at sites representative of a range of habitat types and fishing intensity in the northern Aegean during July 1996 (Fig. 1, Table 1). Prior to operations in each area, a bottom echo-sounder run was undertaken through the proposed investigation area to check bottom depth and topography. A video sledge tow was then made on a lane clear from obstructions with a demersal trawl undertaken on the reverse track.

Video methods. The video sledge used was a modern Marine Laboratory design (Shand \& Priestley 1999). The camera was an Osprey (OE1362 Osprey Electronics, now Kongsberg-Simrad) low light-sensitivecolour camera, mounted on the sledge looking obliquely forward with 2 wide- 
Table 1. Sampling sites details. Sites: $1=$ NW Mytilini, $2=$ West Limnos, $3=$ South Thasos, $4=$ West Skyros, $5=$ Skiathos, $6=$ Pagasitikos, 7 = Evoikos. Nm: nautical miles, D: average depth in metres

\begin{tabular}{|c|c|c|c|}
\hline Site & Location & $\mathrm{D}$ & Fishing pressure \\
\hline 1 & $9 \mathrm{Nm}$ offshore Mytilini & 360 & Fully exploited commercial trawling ground \\
\hline 2 & $5 \mathrm{Nm}$ offshore Limnos & 280 & One of the principal fishery grounds for Nephrops in the N Aegean \\
\hline 3 & $11 \mathrm{Nm}$ south of Thasos & 420 & $\begin{array}{l}\text { Not heavily fished ground with richer grounds found shallower and } \\
\text { inshore }\end{array}$ \\
\hline 4 & Deep sheltered basin & 380 & Heavily fished ground \\
\hline 5 & $\begin{array}{l}\text { Close to Skyros but closer inshore } \\
\text { on the slope of Evia }\end{array}$ & 440 & $\begin{array}{l}\text { Contours of the area do not allow for a long trawl, which is the } \\
\text { probable reason for the lesser degree of commercial activity }\end{array}$ \\
\hline 6 & $\begin{array}{l}\text { Semi-enclosed gulf, approx. } 15 \mathrm{Nm} \\
\text { in diameter. Shallowest occurrence } \\
\text { of Nephrops in Greek waters }\end{array}$ & 80 & $\begin{array}{l}\text { Area closed to bottom trawling as a conservation measure, but } \\
\text { artisanal fishing (gill nets) is allowed on the bottom, with maximum } \\
\text { fishing pressure (April to August) coinciding with the time of female } \\
\text { Nephrops maximum availability on the sediment surface }\end{array}$ \\
\hline 7 & $\begin{array}{l}\text { Small deep basin in the channel } \\
\text { between Evia and the Greek mainland }\end{array}$ & 450 & $\begin{array}{l}\text { Trawling activities are mostly confined to shallower waters in the } \\
\text { same area, because of the poor catches of commercially important } \\
\text { species and the high by-catch of Munida rugosa }\end{array}$ \\
\hline
\end{tabular}

angle $500 \mathrm{~W}$ underwater lighting units (Versabeam, Deep Sea Power \& Light). The camera had a fixed focal length lens and a calibrated field of view of $1 \mathrm{~m}$. Floatation was added to the warp at the sledge end of the cable to prevent the towing cable from disturbing the sediment in front of the sledge. Video recordings were carried out for at least $2 \mathrm{~h}$ (average length of tow $536 \mathrm{~m}$ or $129 \mathrm{~min}$ ). The GPS position of the towing vessel was recorded every $5 \mathrm{~min}$ and the output from the TV camera was recorded on videotape (S-VHS), together with a time signal. The distance covered in each 5 min section could be calculated, and with a calibrated fixed view, the area viewed could also be calculated.

Burrow identifications. Chapman \& Rice (1971) and Rice \& Chapman (1971), through field studies, resin casting and laboratory observations, provided the first detailed descriptions of Nephrops burrows. Since then, burrow construction, burrow maintenance behaviour and adult-juvenile interactions have also been documented (Chapman 1980, Atkinson \& Chapman 1984, Smith 1987, Marrs et al. 1996). A recent comprehensive compilation of existing and new information on the structural complexity of Nephrops burrows as well as a diagnostic burrow identification key is provided by Marrs et al. (1996). Confirmation of identification of the burrows of other species occurring on the same ground as Nephrops was also possible for each ground through trawl-collected material, observation of burrow structure, and in some cases, sightings of emerged animals (e.g. Cepola). To minimise interpretational variability, all burrow identifications and feature measurements were made by dedicated expert observers.

Burrow feature measurements. An area of $0.5 \mathrm{~m}^{2}$ was delimited on the video screen and the number of holes (burrow openings, not assigned to burrow systems or species) present was counted and expressed as total hole density per $\mathrm{m}^{2}$. This was done 30 times on each ground by 'stop-framing' the video image. Holes occurred in various configurations, reflecting the morphologies of the burrow systems. Notes were made of the types, sizes and configuration of openings as this information revealed the identity of some of the burrow-dwelling fauna. The total number of burrow systems present per area was also noted as an indication of burrow diversity. For each section of the video examined, the number of Nephrops burrow openings per burrow system was recorded and the size of the burrows (largest diagonal between burrow openings of each burrow system) was measured. Off-screen measurements of height and width of burrow openings were attempted, but low confidence in the accuracy of such measurements prevented further use of these data.

Nephrops burrow counting methodologies. For estimating Nephrops burrow densities, 3 approaches were adopted.

In situ density: An experienced operator made continual notes of major features viewed including counts of Nephrops burrows in real time whilst the sledge was being towed.

Laboratory density: Four replicate 5 min sections of video from each area were examined in detail in the laboratory with the ability to replay the sections. All Nephrops burrow systems viewed in the centre of the monitor were counted for each period.

DISTANCE density: The same 4 replicate sections of video were examined in the laboratory. Burrow counts along each transect were divided into 3 strips: (1) a central strip ( $1 \mathrm{~m}$ width) comprising the width of the 
field of view at the bottom of the video monitor, where all the burrows present could be counted; (2) a second strip of $50 \mathrm{~cm}$, on either side of the central strip, where burrows that impinged on either side of the sledge track were enumerated (therefore, the total number of burrows in this strip were only partially observed); and (3) a third strip where no part of any burrow could be observed.

The width of the outer strips was based on the overall mean of the maximum distance between 2 openings of a Nephrops burrow (mean: $52 \pm 2.2 \mathrm{~cm} \mathrm{SE}$; range: 14 to $172 \mathrm{~cm}$ ) calculated from measurements of all the Nephrops casts $(\mathrm{n}=148)$ known to the authors (Marrs et al. 1996). For the in situ and laboratory counts, weighted mean burrow densities and variances were used in order to compensate for unequal tow lengths of the 5 min sections (Sokal \& Rohlf 1981).

Nephrops density estimates were calculated as numbers or weight per $\mathrm{m}^{2}$ and were not scaled up to stock size as this was beyond the scope of this study.

The effect of tow length on burrow estimates. As operational and financial constraints may at any time influence decision-making on survey sampling design, an analysis of the effect of the tow length was carried out to allow for recommendations for future surveys. Data from all 7 sites were used in this analysis, and the four 5 min periods of analysed video per site were randomised and joined together to run as a 20 min strip of video. The distance of each burrow from the start of the tow was estimated from the data on tow length calculated from the research vessel position and tow duration. Means were calculated at each $25 \mathrm{~m}$ interval over the course of the bulked tow for each site (the first mean at $25 \mathrm{~m}$ was the number of burrows in the first $25 \mathrm{~m}$ of tow, the next mean at $50 \mathrm{~m}$ was the mean number of burrows in the first and the second $25 \mathrm{~m}$ of the tow and so on) performing 100 random permutations in the replicate sequence (i.e. in the sequence of each of $25 \mathrm{~m}$ intervals). For each of these permutations, the average value was calculated for $1,2,3, \ldots$ up to 27 (= 'max') replicates:

$$
y_{i j}=\sum_{k=1}^{i} \frac{X_{k j}}{i}
$$

where $X_{k j}$ is the abundance value (burrow density) of the $i$ th sample in sequence during the $j$ th random permutation, and $y_{i j}$ is the average value for the first $i$ samples of the $j$ th random permutation.

To estimate the maximal possible error in burrow density, we used the maximal deviation statistic $\left(\mathrm{mD}_{i}\right)$ defined by Rumohr et al. (2001) as the maximal absolute difference between the cumulative average burrow density for each possible subset from the average value for the 'max' replicates per site $\left(y_{\max }\right)$, which may be considered as the value closest to the 'true' mean:

$$
\operatorname{mD}_{i}=\max _{j=1}^{100}\left|\frac{y_{i j}-y_{\max j}}{Y_{\max j}}\right| \times 100
$$

The advantage of this approach is that it provides a measure of the potential error, with no assumption on the distribution of abundance among the replicates (Rumohr et al. 2001).

Trawl methods. The net used was a Greek commercial bottom trawl with $26 \mathrm{~mm}$ cod-end (stretched mesh) and a wingspread of $12 \mathrm{~m}$. Haul duration was approximately $1.5 \mathrm{~h}$, with small deviations because of local topographical peculiarities of the different trawl lanes. On recovery of the cod-end, all species caught were identified, enumerated and weighted. Nephrops carapace length was measured for the entire catch or from a separately weighed sub-sample. Trawl catches were converted to numbers per $\mathrm{m}^{2}$. The size range of Nephrops gave an indication of the size range of Nephrops burrows likely to be encountered and the by-catch data gave some indication of other burrowing species present.

Density of emergent Nephrops. Counts of observed emerged Nephrops (seen on TV) were made from all the video material available per site (ca. 2 h) and given as density estimates per $\mathrm{m}^{2}$. Emergence rates (percentage) of observed and trawled animals were calculated as the density of emerged or trawled animals divided by the burrow density.

\section{RESULTS}

\section{Video appraisal of the grounds, Nephrops and other burrowing megafauna}

From observations of Aegean underwater video material, it was apparent that there were several species of burrowing megafauna associated with the Nephrops grounds. The number and type of such burrowing megafauna varied between grounds (Fig. 2). The mean burrow diversity (number of type of burrows present at each ground) was high with a mean of 5.2 (maximum and minimum of 7 and 4 in Limnos and Skiathos, respectively), while the total number of different burrows seen at these Aegean sites was 15. Burrow diversity is only indicative of the total species diversity present, as some species occupy burrows constructed by others, e.g. various polychaetes, bivalves, squat lobsters and fish (Nickell \& Atkinson 1995, Marrs et al. 1996, Atkinson et al. 1997a). The mean hole density (burrow openings, not assigned to burrow systems or species) ranged between 43 and 5 holes $\mathrm{m}^{-2}$ in Evoikos and Limnos, respectively. A summary of ground-specific features seen on video including evidence of trawling, Nephrops, burrowing megafauna and epibenthos seen on the sediment surface is given in Table 2 . 


\section{Animal and burrow densities}

Maximum density from trawling was found in Pagasitikos. The largest individuals were found in Skiathos and Evoikos, but these were also the least dense populations. The Nephrops from Mytilini had the smallest mean carapace length and by far the smallest mean weight (Table 3). The populations from Limnos, Thasos and Skyros were similar in animal size. The highest burrow densities were in Pagasitikos, similar mediumlevel densities in Mytilini and Limnos, low densities in Thasos, Skyros and Skiathos, and very low densities in Evoikos (Table 4). In almost all cases, the 3 burrow density estimates were similar with 2 exceptions (at the maximum and minimum density sites of Pagasitikos and Evoikos), suggesting a bias in estimation with the in situ technique. The relationship between in situ and laboratory and DISTANCE estimates was non-linear (Table 5). with the in situ technique producing higher burrow densities at low laboratory estimates and lower densities at higher laboratory burrow density estimates. The relationship between burrow estimates and animal density (from trawling) was linear (Table 5). No estimates of variability were given for the Nephrops trawl catches (1 trawl per ground), but burrow density variability was generally higher at the higher density sites, Pagasitikos and Mytilini. The highest variability was seen in the DISTANCE estimates, in some cases, more than double the other 2 estimates. Densities of emerged Nephrops seen on TV were very low, ranging from 0.0001 to $0.0039 \mathrm{~m}^{-2}$. The average emergence rates of observed and trawled Nephrops were 9.9 and $15.0 \%$. Although emergence rates were found to vary with burrow density, in general with higher values in denser grounds, no significant relationships were found (Table 5).

The mean number of burrow openings per burrow system was very similar at 3.0 to 3.5 , while the mean burrow size (mean of largest diagonal between burrow openings of each burrow system) ranged from 53.6 to $86.0 \mathrm{~cm}$. The relationship between burrow size and burrow density was linear with all 3 estimates giving similar negative relationships with similar slope and intercept (Table 5). No significant relationships were found between Nephrops mean carapace length and burrow size, and mean weight and burrow size.

\section{Effect of tow length on burrow density estimates}

The maximal deviation encountered (Fig. 3) ranged from $0 \%$ in Mytilini (at a tow length of $475 \mathrm{~m}$ ) to $100 \%$ in Evoikos (at a tow length of $325 \mathrm{~m}$ ). The percentage maximal deviation decreased substantially with increasing tow length at all 7 sites (e.g. from $400 \%$ for a
$25 \mathrm{~m}$ section to $0 \%$ for $475 \mathrm{~m}$, i.e. $20 \times 25 \mathrm{~m}$ sections in Mytilini). Maximal deviation decreased to a reasonable level at a reasonable tow length with higherdensity areas, leading to a better count over shorter tow lengths.

\section{DISCUSSION}

\section{Burrow and animal densities}

The highest Nephrops density was recorded in the shallowest ground, in Pagasitikos. This is an atypical area in the Aegean with soft muddy sediments in relatively shallow waters and constant cold bottom waters. Unlike the other areas, Pagasitikos is undisturbed by trawling, allowing full development of sedimentary burrowing communities. At substantial, but slightly lower density, Mytilini and Limnos represented 2 fully exploited commercial trawling grounds at 270 to $300 \mathrm{~m}$

a)

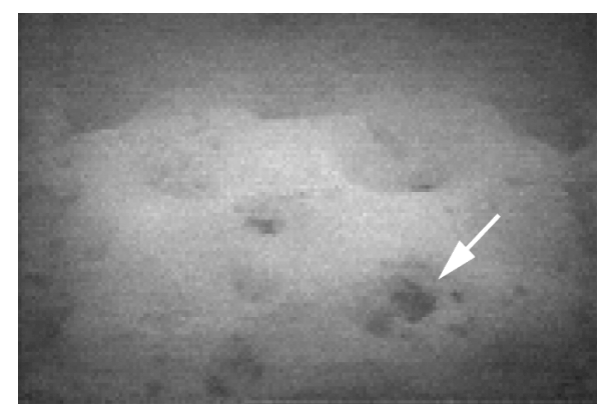

b)

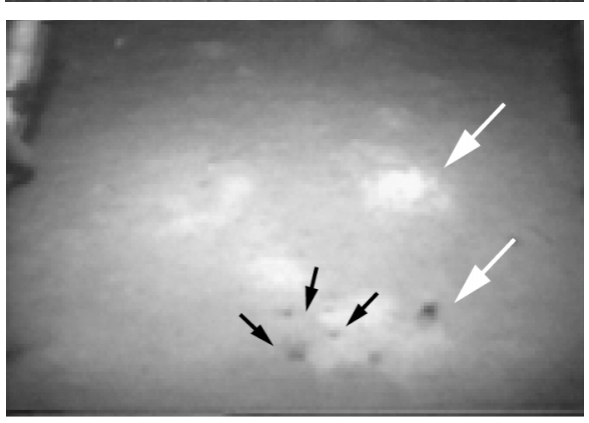

Fig. 2. Aegean Nephrops grounds. The images derive from videotape, hence the lack of resolution, but suffice to give a visual impression of the grounds. The TV camera is looking obliquely forward, frame width $1 / 3$ up from the bottom of the image is $80 \mathrm{~cm}$. (a) Pagasitikos Gulf ( $86 \mathrm{~m}$ depth). Highly bioturbated sea bed in an area where fishing by towed gear is prohibited. A Nephrops burrow (white arrow) is visible amongst burrows of the red band-fish Cepola rubescens. (b) Skiathos (450 m depth). The larger burrow opening, bottom right (white arrow), is that of a small Nephrops. The patch of lighter toned sediment above it (middle right) marks the ejecta at another opening (white arrow) to the same burrow. The cluster of small burrow openings (bottom, marked by black arrows) are those of the Calocaris macandreae burrow 
Table 2. Summary of ground-specific features seen on video. Sediment, Nephrops, other megafaunal burrows and epibenthos seen on sediment surface. S: Sites: $1=$ NW Mytilini, $2=$ West Limnos, $3=$ South Thasos, $4=$ West Skyros, $5=$ Skiathos, $6=$ Pagasitikos, 7 = Evoikos

\begin{tabular}{ll} 
S & \multicolumn{1}{c}{ Sediment } \\
\hline 1 & $\begin{array}{l}\text { Relatively flat sediment. Evi- } \\
\text { dence of recent and wide } \\
\text { scale trawling }\end{array}$ \\
2 & $\begin{array}{l}\text { Flat sediment with little bio- } \\
\text { genical topography. Numer- } \\
\text { ous trawl marks, deep trawl } \\
\text { door gouges and scrapes } \\
\text { from warps and ground } \\
\text { ropes }\end{array}$
\end{tabular}

3 Relatively flat sediment scarce and relatively old trawl marks

4 Heavily trawled ground, with many scrape marks on the sediment surface

5 High biogenic microtopography, signs of recent bioturbation

6 Soft sediments with marked roughness, and high degree of microtopography

7 Heavily burrowed sediment, no signs of recent trawling

\author{
Nephrops and other megafaunal burrows
}

Dense Nephrops burrows. Dense Calocaris macandreae burrows identifiable by their tripartite branching pattern (Nash et al. 1984). Callianassid burrow features (small vertical holes and adjacent ejecta mounds). Occasional 'fairy ring' burrows. Burrows of an unidentified rockling

Nephrops and Calocaris burrows, some in the face of door marks. Clusters of small holes $(<1 \mathrm{~cm})$ suggestive of an upogebiid shrimp. Clusters of 3 or 4 larger holes (1 to $2 \mathrm{~cm}$ ) with distinct excavation traces beside some of them suggestive of Alpheus glaber. Callianassid burrows. An unidentified species with a 'small Nephrops-like' burrow and in some cases, with a single opening. Possible Jaxea nocturna burrow features

Nephrops burrows in low density. Calocaris burrows. Occasional large mounds volcano-like with surrounding holes. 'Small Nephrops-like' burrows. A 'daisy wheel' feeding trace at burrow opening-possibly Maxmuellaria gigas (Atkinson et al. 1997b)

Nephrops burrows in low density. Calocaris and 'small Nephrops-like' burrows. Burrows in volcano-like mounds. 'Fairy rings': a ring of up to 10 small holes sometimes surrounding a central hole in a low mound, suggestive of an enteropneust (Tuck \& Atkinson 1995)

Nephrops burrows in low density. Emergent Nephrops included the largest individuals seen during this survey. Calocaris and 'small Nephrops-like' burrows. Lesueurigobius friesii burrows

Nephrops burrows in high densities. Cepola burrows restricted to 1 area. Dense Calocaris burrows. Goneplax and Lesueurigobius burrows, both species also present in the trawl catch

Nephrops burrows in very low densities. Numerous Calocaris burrows. Bonellia viridis in striking densities (Hughes et al. 1999) with each proboscis emerging from a small hole in the sediment, without any association with sediment mounds. A few Maxmuellaria gigas like-burrows. Burrow features suggestive of Jaxea nocturna
Epibenthos

A few shrimps, the pennatulid Funiculina quadrangularis and a few fish, including the macrurid Coelorinchus coelorincus

The echinoderms Leptometra phalangium (crinoid) and Stichopus regalis (holothuroid) and a few unidentified flatfish

A few shrimps, soft corals (possibly Pennatula) and cerianthid anemones

The pennatulids Virgularia mirabilis and F. quadrangularis (in high numbers). A few shrimps and fish including C. coelorincus

Pennatulids, the crinoid $L$. phalangium, shrimps and macrurid fish

The red band fish Cepola rubescens, the crab Goneplax rhomboides and the goby Lesueurigobins friesii

Bonellia, soft corals, cerianthid anemones and numerous Munida rugosa were seen on the sediment surface depth, while all other grounds had much lower densities of Nephrops burrows. In comparison with other grounds in the North Sea and the Adriatic, Nephrops burrow densities as well as trawl catches are generally low in the Aegean (Anonymous 1994, Marrs et al. 1996, Tuck et al. 1997b). All 3 burrow density estimates produced similar positive significant linear relationships with animal density from trawling. This relationship, seen also elsewhere (Anonymous 1996), seems surprising with so many variables affecting trawl catches, i.e. with availability to capture depending on emergence and emergence varying with animal sex and size, time of the day and season (Bailey et al. 1993). Emergence rates were found to vary with bur- row density, with higher values in denser grounds. However, Tuck et al. (1997a), who paid particular attention to matching trawl sampling with expected times of peak catches, found significant log-linear relationships, suggesting proportionally higher emergence rates of Nephrops at higher burrow densities. The reasons behind this were thought to be either higher burrow occupancy rates or, more likely, that individuals have to spend longer foraging when living at high densities. Nephrops growth appears to be densitydependent in some populations (Bailey \& Chapman 1983, Chapman \& Bailey 1987, Tuck et al. 1997a, Parslow-Williams et al. 2001, Smith et al. 2001). Additionally, both growth and burrow and animal density 
have been linked to sedimentary characteristics and local hydrographic conditions (sea bed temperature, gyres and fronts associated with larval abundance) (Chapman \& Bailey 1987, Chapman \& Howard 1988, Bailey et al. 1995, Hillis 1996, Tuck et al. 1997a, Maynou \& Sardà 2001).

\section{Burrow identification}

Correct burrow recognition and assignment of burrows to species requires an expert observer with indepth experience in viewing underwater features. Marrs et al. (1996) produced a burrow identification key based on features visible at the scale of underwater video, and discuss possible criteria and groundtruthing aids for burrow recognition. Some burrows, such as the larger Nephrops burrows, have speciesspecific features which, if visible, make their identity unmistakable. However, in highly bioturbated areas
Table 3. Mean Nephrops carapace length (CL) and mean weight (W) per ground

\begin{tabular}{|lcc|}
\hline Site & CL $(\mathrm{mm})$ & W $(\mathrm{g})$ \\
\hline Mytilini & 29.84 & 18 \\
Limnos & 31.82 & 24 \\
Thasos & 33.41 & 27 \\
Skyros & 30.72 & 24 \\
Skiathos & 36.82 & 48 \\
Pagasitikos & 34.58 & 30 \\
Evoikos & 35.90 & 40 \\
\hline
\end{tabular}

(as seen by mean hole density or mean burrow diversity), some features would be obscured, and only through very careful examination is burrow identification possible, especially so in the case of small Nephrops. As with burrow recognition, the identification of unoccupied burrows requires an expert observer, as a large proportion of unoccupied burrows is

Table 4. Mean burrow density estimates $\left(\mathrm{m}^{-2}\right)$ using in situ, laboratory and DISTANCE counts and animal density from trawl data $\left(\mathrm{m}^{-2}\right)$

\begin{tabular}{|c|c|c|c|c|c|c|c|}
\hline \multirow[t]{2}{*}{ Site } & \multicolumn{2}{|c|}{ In situ counts } & \multicolumn{2}{|c|}{ Laboratory counts } & \multicolumn{2}{|c|}{ DISTANCE counts } & \multirow{2}{*}{$\begin{array}{c}\text { Trawl } \\
\text { Animal density }\end{array}$} \\
\hline & Burrow density & $95 \% \mathrm{CI}$ & Burrow density & $95 \% \mathrm{CI}$ & Burrow density & $95 \% \mathrm{CI}$ & \\
\hline Mytilini & 0.045 & 0.023 & 0.045 & 0.043 & 0.046 & 0.057 & 0.0164 \\
\hline Limnos & 0.044 & 0.011 & 0.025 & 0.017 & 0.025 & 0.033 & 0.0012 \\
\hline Thasos & 0.012 & 0.008 & 0.012 & 0.011 & 0.014 & 0.009 & 0.0030 \\
\hline Skyros & 0.008 & 0.009 & 0.018 & 0.010 & 0.019 & 0.023 & 0.0024 \\
\hline Skiathos & 0.019 & 0.010 & 0.017 & 0.011 & 0.017 & 0.015 & 0.0008 \\
\hline Pagasitikos & 0.056 & 0.011 & 0.120 & 0.074 & 0.120 & 0.168 & 0.0212 \\
\hline Evoikos & 0.008 & 0.008 & 0.003 & 0.005 & 0.004 & 0.008 & 0.0001 \\
\hline
\end{tabular}

Table 5. Regression results for various relationships on the Nephrops grounds. B.D.: burrow density; Density Emerged: density of emerged Nephrops seen on video; Emerg. Observed: emergence rate of observed animals; Emerg. Trawled: emergence rate of trawled animals; Length: mean carapace length; Weight: mean individual weight

\begin{tabular}{|c|c|c|c|c|c|}
\hline$Y$ variable & $X$ variable & Intercept & Slope & $r^{2}$ & $\mathrm{p}$ \\
\hline In situ B.D. & Ln (Laboratory) & 0.0845 & 0.0146 & 0.7064 & 0.0179 \\
\hline In situ B.D. & Ln (DISTANCE) & 0.0845 & 0.0159 & 0.7128 & 0.0168 \\
\hline Laboratory B.D. & DISTANCE B.D. & 0 & 1.0050 & 0.9993 & 0.0000 \\
\hline Trawl Density & In situ B.D. & 0 & 0.2649 & 0.5664 & 0.0060 \\
\hline Trawl Density & Laboratory B.D. & 0 & 0.1912 & 0.8098 & 0.0005 \\
\hline Trawl Density & DISTANCE B.D. & 0 & 0.1906 & 0.8160 & 0.0004 \\
\hline Density Emerged & Laboratory B.D. & 0.0013 & 0.0240 & 0.3528 & 0.1597 \\
\hline Density Emerged & Ln (Laboratory) & 0.0057 & 0.0009 & 0.4176 & 0.1168 \\
\hline Emerg. Observed & Laboratory B.D. & 0.1305 & 0.9102 & 0.1699 & 0.3581 \\
\hline Emerg. Observed & Ln (Laboratory) & 0.0108 & 0.0282 & 0.1337 & 0.4120 \\
\hline Emerg. Trawled & Laboratory B.D. & 0.1182 & 0.9390 & 0.0923 & 0.5077 \\
\hline Emerg. Trawled & Ln (Laboratory) & 0.3434 & 0.0496 & 0.2030 & 0.3011 \\
\hline Burrow Size & Length & -5.3245 & 2.3852 & 0.3053 & 0.2555 \\
\hline Burrow Size & Weight & 59.7918 & 0.4570 & 0.1820 & 0.3988 \\
\hline In situ B.D. & Burrow Size & 0.1130 & -0.0012 & 0.7423 & 0.0274 \\
\hline Laboratory B.D. & Burrow Size & 0.1027 & -0.0011 & 0.9157 & 0.0027 \\
\hline DISTANCE B.D. & Burrow Size & 0.1017 & -0.0011 & 0.8865 & 0.0050 \\
\hline
\end{tabular}




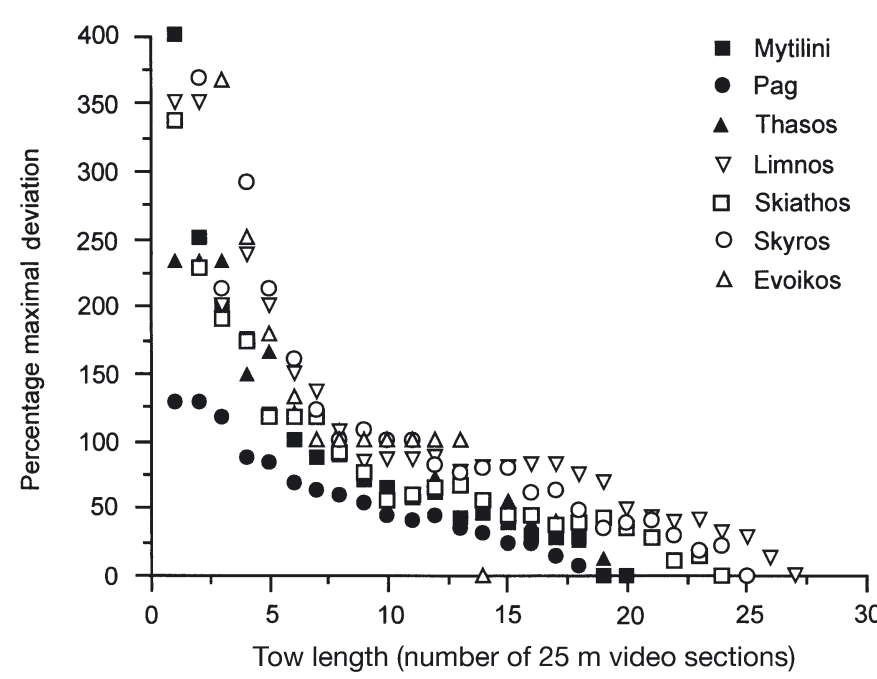

Fig. 3. Percentage maximal deviation versus video tow length (in numbers of $25 \mathrm{~m}$ video sections) analysed per station

a potential cause for density overestimation. The number of unoccupied burrows should be proportionally higher where fishing effort is higher, although bottom fishing will tend to cause collapse and remove traces of those burrows directly under the trawl track. Occupied burrows require constant maintenance, keeping openings unobstructed, preventing collapse and digging new tunnels. Unoccupied burrows may be identified by obstructions in the burrow openings or partial collapse of the openings, traces of which may last several months (see Marrs et al. 1996, 1998 for criteria for assessing burrow occupancy). To assess the burrow identification and occupancy accuracy, a comparative exercise of expert observers was conducted (Marrs et al. 1996) involving the designated observers of this paper, counting Nephrops burrows along the same 10 min video section with results showing a very good measure of agreement ( $<3 \%$ variability). Addison \& Bell (2000) conducted a similar exercise between 2 experienced observers from CEFAS (Centre for Environment, Fisheries and Aquaculture Science) Lowestoft and 2 equally experienced observers from FRS (Fisheries Research Services) Aberdeen with results being very consistent between counters from the same laboratory. A degree of discrepancy found between laboratories was thought to be due to operational differences (steeper vs shallow obliquely forward camera angle used).

\section{Burrow size and prediction of occupant size}

The mean number of burrow openings (3.3) per Nephrops burrow system was very similar to that found in Scottish waters (3.2) from diver-recovered resin casts (Marrs et al. 1998). The mean burrow sizes found in the Aegean, however, ranged between 54 and $86 \mathrm{~cm}$, producing a larger mean size than that recorded from Scottish waters $(52 \mathrm{~cm})$. This is in agreement with the lower Aegean densities, and the burrow size was found to be inversely related to burrow density. Despite its usefulness in any stock assessment, predictions of occupant size were not possible as no significant relationships were found between burrow size (largest diagonal between openings) and mean Nephrops carapace length or mean weight. While it is possible that such a relationship may not be applicable across grounds, further work is clearly needed with burrow dimension data on burrow opening height and width, acquiring accurate measurements from digital image analysis tools. Obtaining a measure of recruitment (by separating pre- and post-recruit burrow sizes) and estimating the size distribution of Nephrops by the UWTV method are 2 areas for further research and development (Addison \& Bell 2000, Anonymous 2000).

\section{Choice of counting methodology}

In situ counts were the quickest since they were undertaken 'live'. Results could, in theory, be analysed on board for immediate presentation after a sampling cruise. However, it was the most liable to error, as even the most experienced observer is not able to review particular features of burrow morphology or burrow system configuration at speed. Some bias was found in this methodology, producing higher values at low burrow density and lower values at high burrow density. With the observer being able to rewind, play slowly and pause images, the 2 laboratory methods gave very similar results. Although a relatively slow and more complex analysis, the advantage conferred by DISTANCE over laboratory counts is that effectively, a greater area of seabed is sampled per unit length of tow, taking into account partial and missing observations over a set strip (edge effects) along with the potential for more robust density estimates. Further work with DISTANCE should include simulations with hypothetical data to optimise band widths, as this should relate to the expected size of a burrow system. The band width chosen here was based on 148 resin casts measurements from the Clyde Sea (Marrs et al. 1996). However, a number of these burrow casts exhibited adult/juvenile interactions including features not visible at the scale of underwater video technique, and are partly responsible for lowering the mean value of burrow size. On the other hand, new data (this study) and anecdotal observation (Fladen Ground: Addison \& Bell 2000) 
suggest that in certain low burrow density stocks, burrows may be far larger than those observed in higher density stocks (e.g. Clyde Sea area or Firth of Forth). To date, most research groups do not correct their burrow abundance estimates for edge effects (counts include burrows wholly in the field of view and burrows extending out of the field of view) as counts are intended as an index of abundance and this error is assumed to be constant across surveys. However, edge effects will be greater in areas with larger burrows and will vary with operational set-up (i.e. differences in camera angle and width of view, towing speed, weight of the sledge/contact with seabed). Addison \& Bell (2000) reported potential overestimates due to edge effects to range between 25 and $34 \%$, based on empirical and theoretical inputs that did not include DISTANCE. The application of laboratory and DISTANCE counts in the present study was an attempt to account for edge effects towards quantitative density estimates rather than a tool for across-ground comparisons.

\section{Sampling efficiency}

Operational and financial constraints could affect sampling and data analysis design with serious repercussions on density estimates and fishery-independent stock assessments. Acceptable tow lengths or area viewed (tow length $\times$ field of view) will vary between grounds and will depend on a number of factors, including Nephrops density and patchiness of distribution. Stratification is an important component of survey design, and any stratification that reduces variance within individual strata will improve the survey (Addison \& Bell 2000). Based on the maximal deviation statistic (Rumohr et al. 2001) and the tow lengths analysed in the present work, the use of tow lengths of 500 and $1000 \mathrm{~m}$ per station for high- and mid-range/low-density sites, respectively, is recommended.

With expert analysts, laboratory counts, trawl support data, accurate delimitation of the grounds and adequate replication/sampling spread to allow for local stock variability differences, the UWTV technique can be used for fishery-independent stock assessments and its precision refined by taking into account edge effects.

Acknowledgements. The support of the EC DG14 through the funding of the Study Project 94/069 'Calibration of the towed underwater TV technique for use in stock assessment of Nephrops norvegicus' is gratefully acknowledged. The skipper and crew of RV 'Philia' (Institute of Marine Biology of Crete) are thanked for their support during sampling. Thanks are also due to 4 anonymous reviewers for helpful comments on the manuscript.

\section{LITERATURE CITED}

Addison JT, Bell MC (2000) Report of the Study Group on life history of Nephrops. ICES-CM 2000/G:06 Ref. ACFM: 104-111

Anonymous (1994) Nephrops norvegicus: stock variability and assessment in relation to fishing pressure and environmental factors. EC DGXIV Final Report, Study Project 91/003

Anonymous (1996) Report of the Study Group on life history of Nephrops. ICES-CM 1996/K:2 Ref. Assess

Anonymous (1999) Report of the Study Group on life history of Nephrops. ICES-CM 1999/G:13 Ref. ACFM

Anonymous (2000) Report of the Study Group on life history of Nephrops. ICES-CM 2000/G:06 Ref. ACFM

Anonymous (2001) Overview of Nephrops stocks. ICES-CM 2001/ Ref. ACFM:247-248

Atkinson RJA, Chapman CJ (1984) Resin casting: a technique for investigating burrows in sublittoral sediments. Prog Underw Sci 9:15-25

Atkinson RJA, Froglia C, Arneri E, Antolini B (1997a) Observations on the burrows and burrowing behaviour of Squilla mantis (L.) (Crustacea: Stomatopoda). PSZN I: Mar Ecol 18:337-359

Atkinson RJA, Froglia C, Arneri E, Antolini B (1997b) Observations on the burrows and burrowing behaviour of Brachynotus gemmellari and on the burrows of several other species occurring on Squilla grounds off Ancona, Central Adriatic. Sci Mar 62(1-2):91-100

Bailey N, Chapman CJ (1983) A comparison of density, length composition and growth of 2 Nephrops populations off the west coast of Scotland. ICES-CM K:42

Bailey N, Chapman CJ, Kinnear J, Bova D, Weetman A (1993) Estimation of Nephrops stock biomass on the Fladen Ground by TV survey. ICES-CM K:34

Bailey N, Chapman CJ, Afonso-Dias M, Turrell W (1995) The influence of hydrographic factors on Nephrops distribution and biology. ICES-CM Q:17

Briggs RP, Armstrong MJ, Dickey-Collas M, Allen M, McQuaid N, Whitmore J (2002) The application of fecundity estimates to determine the spawing stock biomass of Irish Sea Nephrops norvegicus (L.) using the annual larval production method. ICES J Mar Sci 59(1):109-119

Buckland ST, Anderson DR, Burnham KP, Laake JL, Borchers DL, Thomas L (2001) Introduction to distance sampling. Oxford University Press, Oxford

Caddy JF (1975) Spatial model for an exploited shellfish population, and its application to Georges Bank scallop fishery. J Fish Res Board Can 32:1305-1328

Chapman CJ (1980) Ecology of juvenile and adult Nephrops. In: Cobb S, Phillips B (eds) The biology and management of lobsters, Vol II. Academic Press, New York, p 143-178

Chapman CJ, Bailey N (1987) Biological research on fish and shellfish stocks: recent progress in Norway lobster research. In: Bailey RS, Parrish BB (eds) Developments in fisheries research in Scotland. Fishing News Books, Farnham, p 99-111

Chapman CJ, Howard FG (1988) Environmental influences on Norway lobster (Nephrops norvegicus) populations and their implications for fishery management. Symp Zool Soc Lond 59:343-353

Chapman CJ, Rice AL (1971) Some direct observations on the ecology and behaviour of the Norway lobster Nephrops norvegicus (L.). Mar Biol 10:321-329

Hillis JP (1996) Factors affecting catchability in Nephrops: current speed. ICES-CM K:21

Hughes DJ, Marrs SJ, Smith CJ, Atkinson RJA (1999) Obser- 
vations of the echiuran worm Boneliia viridis in the deep basin of the northern Evoikos Gulf, Greece. J Mar Biol Assoc UK 79:361-363

Marrs SJ, Atkinson RJA, Smith CJ, Hills JM (1996) Calibration of the towed underwater TV technique for use in stock assessment of Nephrops norvegicus. EC DGXIV Final Report, Study Project 94/069

Marrs SJ, Atkinson RJA, Smith CJ, Hills JM (1998) The towed underwater TV technique for use in stock assessment of Nephrops norvegicus. ICES-CM G9:88-98

Maynou F, Sardà F (2001) Influence of environmental factors on commercial trawl catches of Nephrops norvegicus (L.). ICES J Mar Sci 58:1318-1325

Nash RDM, Chapman CJ, Atkinson RJA, Morgan PJ (1984) Observations on the burrows and burrowing behaviour of Calocaris macandreae Bell (Crustacea: Decapoda: Thalassinoidea). J Zool Lond 202:425-439

Nichols JH, Bennett BD, Symonds DJ, Grainger R (1987) Estimation of the stock size of adult Nephrops norvegicus (L.) from larval surveys in the western Irish Sea. Symp Zool Soc Lond 59:157-175

Nickell LA, Atkinson RJA (1995) Functional morphology of burrows and trophic models of three species of thalassinidean shrimp species, and a new approach to the classification of thalassinidean burrow morphology. Mar Ecol Prog Ser 128:181-197

Parslow-Williams PJ, Atkinson RJ, Taylor AC (2001) Nucleic acids as indicators of nutritional condition in the Norway lobster Nephrops norvegicus. Mar Ecol Prog Ser 211:235-243

Rice AL, Chapman CJ (1971) Observations on the burrows and burrowing behaviour of two mud-dwelling decapod crustaceans, Nephrops norvegicus and Goneplax rhomboides. Mar Biol 10:330-342

Rumohr H, Karakassis I, Jensen JN (2001) Estimating species

Editorial responsibility: Otto Kinne (Editor),

Oldendorf/Luhe, Germany richness, abundance and diversity with 70 macrobenthic replicates in the Western Baltic Sea. Mar Ecol Prog Ser 214:103-110

Shand CW, Priestley R (1999) A towed sledge for benthic surveys. Scottish Fisheries Information Pamphlet 22/1999. Fisheries Research Services, Aberdeen

Smith CJ, Papadopoulou KN, Kallianiotis A, Vidoris P, Chapman CJ, Vafidis D (2001) Growth and natural mortality of Nephrops norvegicus, with an introduction and evaluation of creeling in Mediterranean waters. EC DG XIV Final Report, Study Project 96/013

Smith RSM (1987) The biology of larval and juvenile Nephrops norvegicus (L.) in the Firth of Clyde. PhD thesis, University of Glasgow

Sokal RR, Rohlf FJ (1981) Biometry: the principles and practice of statistics in biological research. WH Freeman, New York

Thomas L, Buckland ST, Burnham KP, Anderson DR, Laake JL, Borchers DL, Strindberg S (2002) Distance sampling. In: El-Shaarawi AH, Piegorsch WW (eds) Encyclopedia of environmetrics. John Wiley, Chichester, p 544-552

Tuck ID, Atkinson RJA (1995) Unidentified burrow surface trace from the Clyde sea area. Neth J Res 34:331-335

Tuck ID, Chapman CJ, Atkinson RJA (1997a) Population biology of the Norway lobster Nephrops norvegicus (L.) in the Firth of Clyde, Scotland. I. Growth and density. ICES J Mar Sci 54:123-135

Tuck ID, Chapman CJ, Atkinson RJA, Bailey N, Smith RSM (1997b) A comparison of methods for stock assessment of the Norway lobster, Nephrops norvegicus in the Firth of Clyde. Fish Res 32:89-100

Tuck ID, Bailey N, Atkinson RJA, Marrs SJ (1999) Changes in Nephrops densities in the Clyde Sea area, from underwater TV survey data. ICES-CM G13:24-31

Submitted: June 18, 2002; Accepted: February 28, 2003

Proofs received from author(s): June 17, 2003 